\title{
Resistance to fracture due to cyclic fatigue of stainless steel manual files and its association to surface roughness
}

\author{
Javier L. Niño-Barrera ', José A. Sánchez-Alemán ', Luis Gamboa-Martinez 2, Carlos \\ Cortes-Rodriguez ${ }^{3}$
}

1. Universidad Nacional de Colombia, Facultad de Odontología, Departamento de Ciencias Básicas y Medicina Oral, Posgrado de Endodoncia, Bogotá, Colombia.

2. Universidad el Bosque, Facultad de Odontología, Posgrado de Endodoncia, Bogotá, Colombia.

3. Universidad Nacional de Colombia, Facultad de ingeniería, Departamento de mecánica y mecatrónica, Bogotá, Colombia

\begin{abstract}
The aim of this study was to evaluate the possible association between the roughness of 5 brands of stainless steel endodontic files and their resistance to fracture due to cyclic fatigue. The study included five different brands of stainless steel endodontic files: SybroEndo Triple-Flex Files (Kerr, Glendora, USA), Ready Steel K-Flexofile (Dentsply Sirona, Ballaigues, Switzerland), Mani Flexile Files (Mani, Tochigi- Ken, Japan), FKG K-Files (FKG, La Chaux-de-Fonds, Switzerland) and Zipperer Flexicut Files (VDW, Munich, Germany). Twelve files per brand (total 60 files) were evaluated. File surface roughness over an area (Sa) was quantified using a focus variation microscope. Then the files were subject to a cyclical fatigue test to determine the number cycles to fracture due to fatigue and length of fractured fragment. Finally, fractographic analysis was performed using
\end{abstract}

a scanning electron microscope. The electropolished Ready Steel K-Flexofile ${ }^{\circledR}$ files had the highest roughness according to Sa parameters, though they also had the highest resistance to fracture due to cyclic fatigue and the longest fractured fragment. Moderate positive correlation was found between fractured fragment length and roughness. The fractured surface showed characteristics of ductile fracture with cracks and plastic deformation. The electropolished stainless steel Ready Steel $K$-Flexofile ${ }^{\circledR}$ files were the most resistant to fracture due to cyclic fatigue even though they had highest surface roughness. Received: November 2019; Accepted: February 2021.

Keywords: dental instruments - endodontics - flexural strength - root canal preparation - stainless steel.

\section{Resistencia a la fractura por fatiga cíclica de las limas manuales de acero inoxidable y su relación con la rugosidad superficial}

\section{RESUMEN}

El objetivo del presente estudio fue evaluar la posible asociación entre la rugosidad de 5 marcas de limas endodónticas de acero inoxidable y su resistencia a la fractura por fatiga cíclica. Se incluyeron cinco grupos diferentes de limas endodónticas de acero inoxidable: SybroEndo Triple-Flex Files (Kerr, Glendora, EE. UU.), Ready Steel K-Flexofile (Dentsply Sirona, Ballaigues, Suiza), Mani Flexile Files (Mani, TochigiKen, Japón), FKG K-Files (FKG, La Chaux-de-Fonds, Suiza) y Zipperer Flexicut Files (VDW, Munich, Alemania); se evaluaron doce instrumentos por grupo para un total de 60 limas. Mediante un microscopio de variación focal se cuantificó la rugosidad superficial por área (Sa) de los instrumentos, posteriormente fueron sometidos a una prueba de fatiga cíclica donde se determinó el número de ciclos de fractura por fatiga y la longitud del fragmento fracturado. Finalmente, se realizó un análisis fractográfico mediante microscopía electrónica de barrido. Las limas Ready Steel K-Flexofile ${ }^{\circledR}$ con electropulido mostraron el mayor valor de rugosidad en los parámetros Sa; sin embargo, también tenían la mayor resistencia a la fractura por fatiga cíclica y la mayor longitud del fragmento fracturado del instrumento. Además, se encontró una correlación moderada positiva entre la longitud del fragmento fracturado y la rugosidad. La superficie fracturada mostró características de fractura dúctil con grietas y deformación plástica. Las limas Ready Steel K-Flexofile ${ }^{\circledR}$ fabricadas en acero inoxidable con electropulido, fueron más resistentes a la fractura por fatiga cíclica a pesar de tener la mayor rugosidad superficial..

Palabras clave: acero inoxidable - endodoncia - fatiga cíclica - instrumentos dentales - preparación del conducto radicular. 


\section{INTRODUCTION}

Endodontic files have surface features, resulting from their manufacturing process, which affect their resistance to fracture due to cyclic fatigue. The presence of surface roughness on endodontic files has been reported to concentrate stress, giving rise to areas where cracks initiate during clinical use ${ }^{1}$, leading to fracture due to cyclic fatigue ${ }^{2}$.

To date, mechanical, physical and heat surface treatments have been reported for stainless steel alloys -including sanding, grinding, abrading, electropolishing, nitriding, and combined plasma carburizing, among others- to alter surface texture and improve properties such as microhardness and resistance to fracture due to fatigue of the alloy ${ }^{3-5}$.

However, in contrast to nickel-titanium files, stainless steel alloy files have not often been subjected to procedures to improve their properties, even though they are so frequently used in endodontic treatment. In general, there are reports of prevalence of fractures in stainless steel endodontic files of up to $7.4 \% \%^{6}$, which justifies the development of manufacturing techniques which could increase their useful life.

For nickel-titanium instruments, it has been reported that low surface roughness is associated to higher resistance to fracture due to cyclic fatigue ${ }^{7}$. However, for stainless steel alloys, electropolishing may not be associated to an increase or decrease in surface roughness, because it may produce a regular surface with micro-deformation that is not necessarily detrimental to resistance ${ }^{8}$.

Although it has been reported that surface treatment of stainless steel medical devices has a significant effect on roughness, it is not clear whether such roughness causes higher or lower resistance to cyclic fatigue?.

There is no report in the literature on evaluation of surface roughness of stainless steel endodontic files, and therefore no report analyzing the association between their roughness and fracture due to cyclic fatigue.
The aim of this study was thus to assess the possible association between surface roughness and resistance to fracture due to cyclic fatigue in 5 brands of stainless steel endodontic files. The null hypothesis is that there is no difference in roughness and resistance to fracture due to cyclic fatigue in the stainless steel endodontic files evaluated.

\section{MATERIAL AND METHODS}

This was an experimental in vitro study. Probabilistic sample size was calculated with a power of $80 \%$ and significance level 5\%. Sample size per group was thus 12 manual stainless steel endodontic files No. 25, with length 25 $\mathrm{mm}$ long and taper 0.02 , which had not been used previously. Total sample consisted of 60 files of 5 different brands: A: SybroEndo TripleFlex Files (Kerr, Glendora, USA); B: Ready Steel K-Flexofile (Dentsply Sirona, Ballaigues, Switzerland); C: Mani Flexile Files (Mani, Tochigi- Ken, Japan); D: FKG K-Files (FKG, La Chaux-de-Fonds, Switzerland); E: Zipperer Flexicut Files (VDW, Munich, Germany).

\section{Surface finish/roughness}

Three-dimensional measurements were considered to analyze the topography of the stainless steel using $S a$ area parameters. This analysis was performed using an Alicona Infinite Focus G5 focus variation microscope (FVM) (IFM, Alicona Imaging, Grambach, Graz, Austria). The handle of each file was attached to a mini chuck (Alicona Imaging, Grambach, Graz, Austria) adapted to the microscope (Fig. 1). Each file was adjusted in the $3 \mathrm{D}$ rotation unit. The instrument was positioned and focused, taking a value of 0 for the coordinates of axes X, Y and Z. It was moved automatically towards the lens at a distance of $-3.5 \mathrm{~mm}$ on axis $\mathrm{X}$ to locate it on the respective point measured at 20x, after which the $160 \mu \mathrm{m} * 160$ $\mu \mathrm{m}$ measurement window was defined. The $S a$ parameters were measured using the Surface Texture Measurement module of the MeX 6.1 software (Alicona Imaging, Grambach, Graz, 

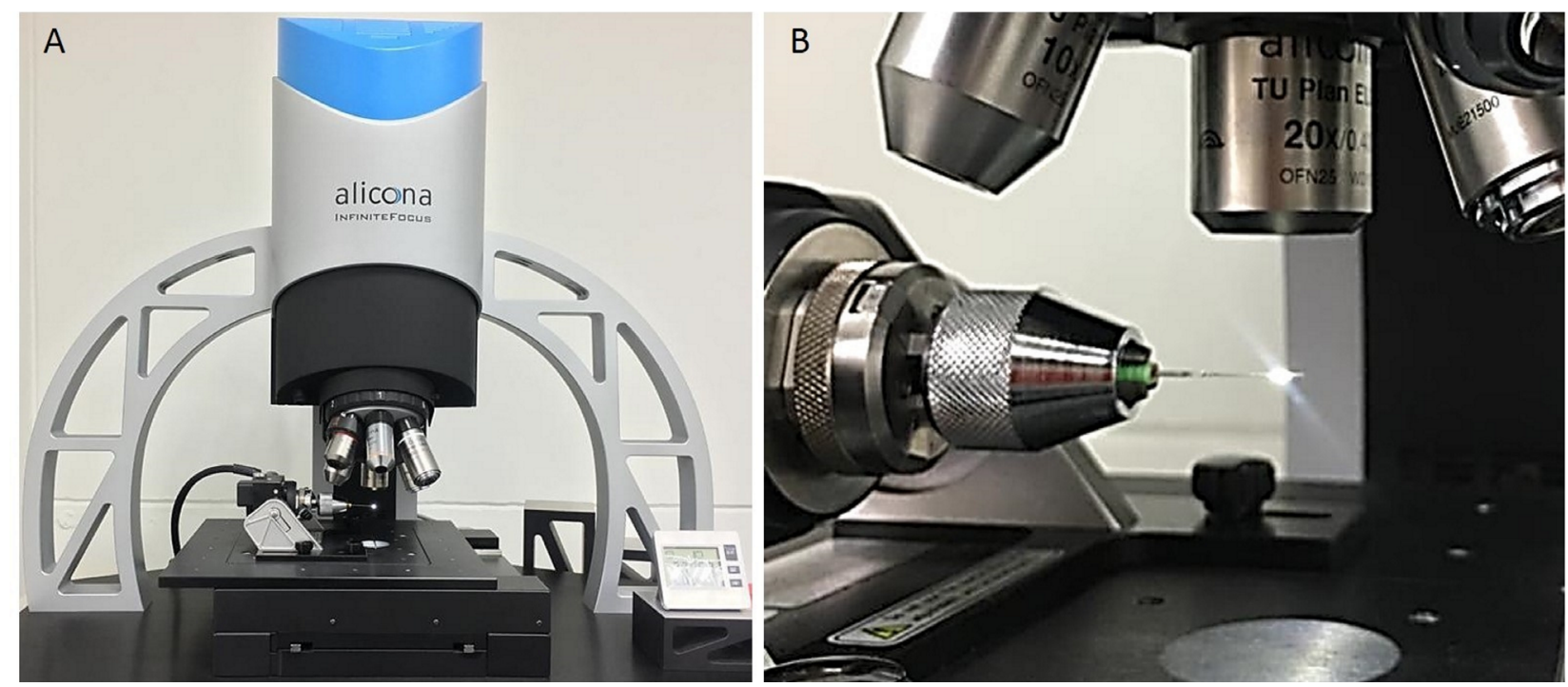

Fig. 1: A. Focus variation microscope (FVM). B. Endodontic file attached to the $3 D$ rotation unit of the FVM by means of a chuck.

Austria). Surface roughness over an area $(\mathrm{Sa})$ was evaluated for each file at four sites: $3.5 \mathrm{~mm}$, $4.5 \mathrm{~mm}, 5.5 \mathrm{~mm}$ and $6.5 \mathrm{~mm}$ from the tip of the file.

\section{Cyclic fatigue}

Cyclic fatigue was tested using an ad hoc device (Fig. 2A) which included a simulated root canal made of stainless steel, designed and built as described by Lopes et al. ${ }^{7}$ and Rodrigues et al. ${ }^{10}$, with curvature $86^{\circ}$, diameter $1.5 \mathrm{~mm}$, radius of curvature $6 \mathrm{~mm}$ and total length $21 \mathrm{~mm}$. The curved segment of the canal measured $9 \mathrm{~mm}$, the longest straight segment $8 \mathrm{~mm}$ and the shortest straight segment $4 \mathrm{~mm}$.

Each file was placed in a mini chuck (Electric Drill Bit Collet, Mini Twist Drill Tool Chuck Set Pretty RF, Koyot, Shangai, China) adapted to a shaft and powered by an endodontic motor (Fig. 2B). The active parts of the manual files were placed and secured in this device. Once in position, a dynamic cyclic fatigue test was conducted using the TriAuto ZX rotary motor (J. Morita Corp., Kyoto, Japan) at $280 \mathrm{rpm}$ in continuous rotation with axial in-and-out movement of the file, with stroke $4 \mathrm{~mm}$ and frequency $1 / 3 \mathrm{~Hz}$, until the file fractured. Synthetic lubricant (WD-40 Company, Milton Keynes, England) was used in all groups to reduce friction.

Cyclic fatigue time to fracture was measured with a digital chronometer. Number of cycles to fatigue (NCF) for each file was calculated by multiplying time to fracture (s) by motor rotations per minute (rpm), divided by $60^{11}$. The fractured

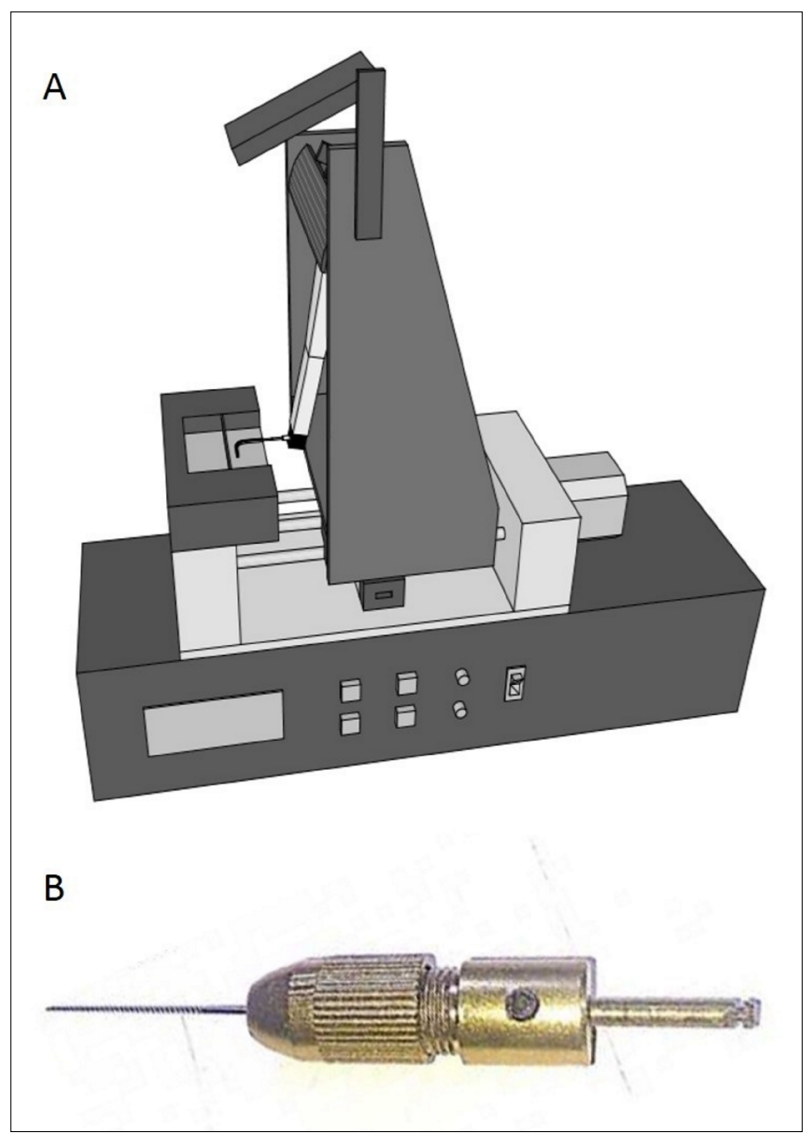

Fig. 2: Devices used to evaluate cyclic fatigue. A. Diagram of the cyclic fatigue device used. B. Mini Twist Drill Tool with machined adjustment for use in endodontic rotary motor. 
fragment of each file was measured with a digital caliper (Digimess, Sao Paulo, SP, Brazil).

\section{Scanning Electron Microscopy}

To observe the features of the fractured surface, one file per group was selected randomly and cleaned ultrasonically to eliminate debris, and examined with a TESCAN VEGA 3 scanning electron microscope (Libusina tr, Brno-Kohoutovice, Czech Republic) at 500x magnification.

\section{Statistical analysis}

Data were initially analyzed with ShapiroWilk's test, and showed non-normal distribution $(p=0.001)$. Then, the Kruskal-Wallis test was applied to analyze roughness, file time to fracture and NCF. Finally, Spearman's correlation coefficient test was applied between file roughness and fracture level to determine whether they were associated. Statistical significance level was 5\%. Software was Stata 12 (StataCorp, Texas, USA).

\section{RESULTS}

Table 1 shows the results for roughness by evaluation with FVM, cyclic fatigue, length of fractured fragment and number of fractured cases per level (distance from tip). The Ready Steel K-Flexofile ${ }^{\circledR}$ files had the highest roughness $(S a)(\mathrm{p}=0.0001)$, highest resistance to fracture due to cyclic fatigue $(\mathrm{p}=0.0001)$ and longest fractured fragments $(\mathrm{p}=0.000)$.

A $54 \%$ association was found between file roughness and fracture level according to Spearman's test, indicating moderate positive correlation $(\mathrm{rho}=0.5440, \mathrm{p}=0.000)$. This means that the fractured fragments of the least rough files were closer to the tip of the instrument, whereas the fractured fragments of the roughest files were farther from the tip of the instrument.

Figure 3 shows the surface roughness evaluated by FVM for the different groups of stainless steel files. After fractographic analysis of the surface, SEM can be used to observe the characteristics of ductile fractures with cracks, plastic deformation and fibrous areas with dimples (Fig. 4).

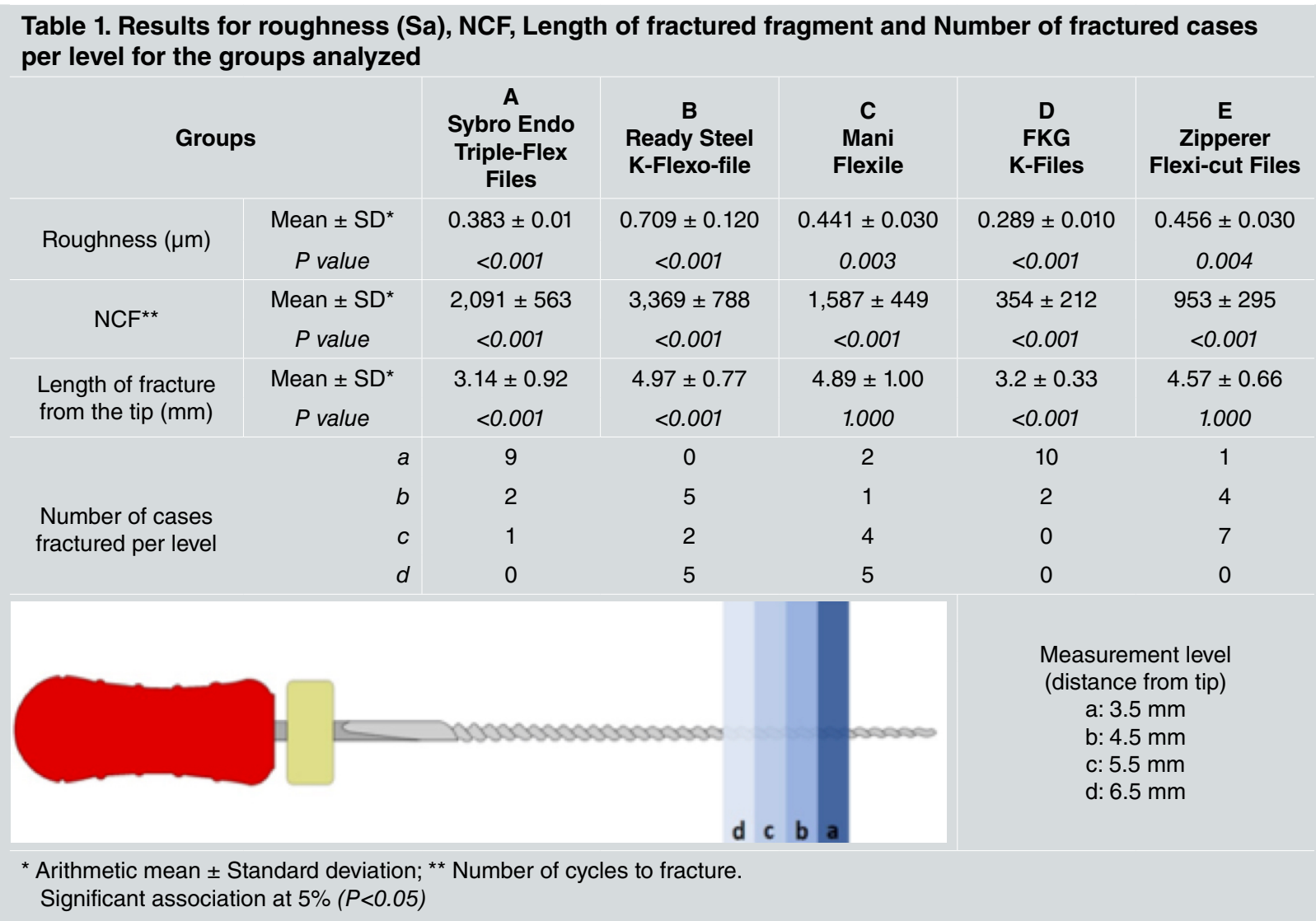




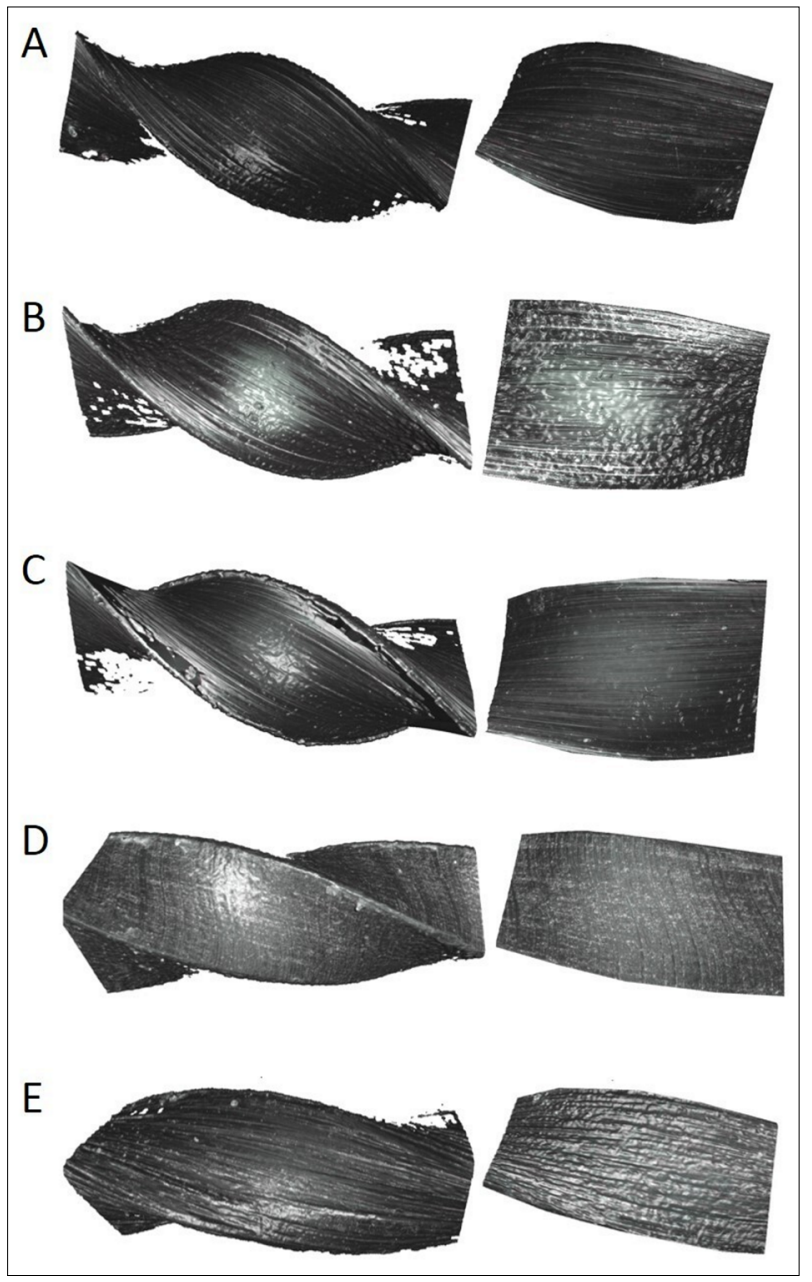

Fig. 3: Topographic images taken with FVMat 20x magnification (left) and their respective $160 \times 160 \mu \mathrm{m}$ fields of measurement (right) for the 5 groups evaluated. A. SybroEndo Triple-Flex Files ${ }^{\circledR}$; B. Ready Steel K-Flexofile ${ }^{\circledR}$, which had the greatest roughness; C. Mani Flexile Files ${ }^{\circledR} ; D$. FKG K-Files ${ }^{\circledR}$, which had the lowest roughness; and E. Zipperer Flexicut Files ${ }^{\circledR}$.

\section{DISCUSSION}

Stainless steel endodontic files are useful for endodontic treatment because they provide greater tactile sensitivity than nickel-titanium files, which is helpful for determining the internal anatomy of the root canal ${ }^{12}$. Moreover, the use of stainless steel is needed as a complement to the handling protocols of various nickeltitanium rotary systems $\mathrm{s}^{13-15}$.

The concept of cyclic fatigue has been adopted in endodontics regarding the application of repeated alternate tension and compression forces ${ }^{16}$. Based on this idea, purely mechanical tests have been proposed to evaluate whether parameters such as heat treatments ${ }^{17}$, speed of rotation ${ }^{18}$ or roughness ${ }^{7}$ can affect file resistance to fracture due to cyclic fatigue in endodontics. Thus, even though the current study evaluated stainless steel files, tests like the ones used in the current study for evaluating cyclic fatigue in endodontic files are valid and have been widely reported in the literature on endodontics ${ }^{7,10,19}$.

The fatigue model used in the current study at ambient temperature provides a valid, reproducible simulation of the clinical setting, since, according to recently reported information ${ }^{20}$, body temperature does not interfere with the result of the cyclical fatigue test. Body temperature is counteracted by factors such as the low thermal conductivity of dentin $^{21}$ and the cooling action of the irrigant within the root canal ${ }^{22}$, which allow the fatigue test to be performed at ambient temperature without altering its clinical relevance ${ }^{20}$.

Haikel et al. ${ }^{23}$ evaluated the resistance to cyclic fatigue of six types of stainless steel manual files in a simulated root canal at $60^{\circ}$ in dynamic fatigue, finding that Flexofile ${ }^{\circledR}$ instruments had the greatest resistance to cyclic fatigue. This is

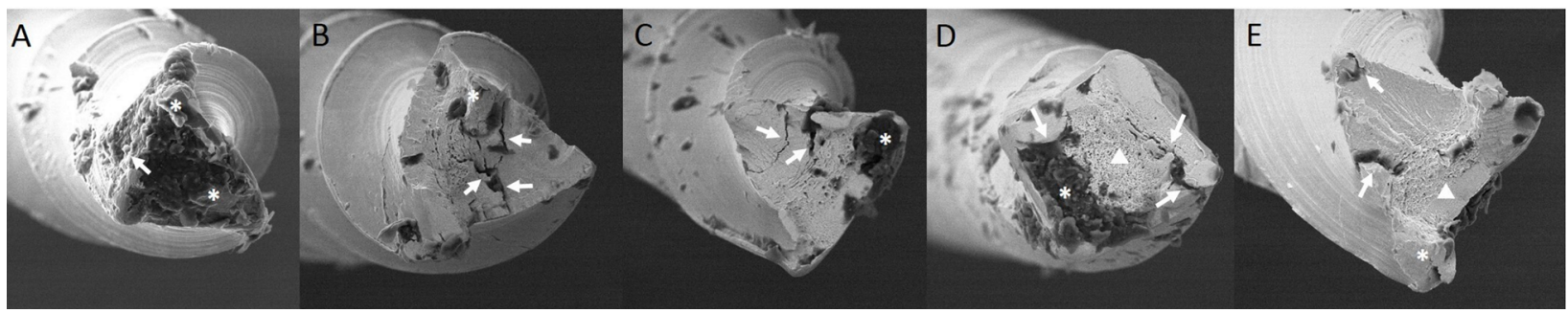

Fig. 4: Scanning electron microphotographs of the fractured surface of the 5 groups analyzed at 500x magnification. A. SybroEndo Triple-Flex Files ${ }^{\circledR} ;$ B. Ready Steel K-Flexofile ${ }^{\circledR} ;$ C. Mani Flexile ${ }^{\circledR} ;$ D. FKG K-Files ${ }^{\circledR}$; and E. Zipperer Flexicut Files ${ }^{\circledR}$. The images show ductile fractures with cracks (white arrows), plastic deformation (asterisks) and fibrous areas with presence of dimples (arrowheads). 
similar to our results, which also found that the group Ready Steel K-Flexofile ${ }^{\circledR}$ had the greatest resistance to fracture due to cyclic fatigue.

Gambarini et al. ${ }^{24}$ compared the resistance to cyclic fatigue between nickel-titanium Pathfile ${ }^{\circledR}$ files and stainless steel k-type files for use with the reciprocating handpiece M4®, also in a simulated $60^{\circ}$ stainless steel root canal. They found that M4 stainless steel files were more resistant to fracture due to cyclic fatigue. Although it is clear that their reciprocating motion had definitive impact on the results, they present stainless steel files as a possible alternative for rotatory mechanical instrumentation. These findings agree with our results, as we too found that stainless steel endodontic files had good resistance to fracture due to cyclic fatigue.

Piasecki et al. ${ }^{25}$ reported an experiment with stainless steel and carbon steel Pathfinder ${ }^{\circledR}$ instruments in double curved root canals (middle third $60^{\circ}$ and apical $70^{\circ}$ ), also using the M4® handpiece with reciprocating motion, finding no significant difference between the two groups evaluated. Our results showed a longer time to fracture due to cyclic fatigue, comparable to the time reported by Piasecki et al. ${ }^{25}$ for the group of stainless steel files. However, it is important to consider that we performed the evaluation in a continuous rotary motion rather than the reciprocating motion used by Piasecki et $\mathrm{a}^{25}$.

Roughness has generally been evaluated in profile or area parameters. In the literature, the most frequently used profile parameter is $R a$, and the most frequently used area parameter is $S a^{26}$. The following advantages have been reported for the $S a$ parameter over the $R a$ parameter: better topographic evaluation of three-dimensional surface; $R a$ roughness parameter depends on the direction in which the profile is drawn, while $S a$ roughness parameter takes the average of the spikes in a given area, so its results have been considered more reliable ${ }^{26,27}$.

In contrast to nickel-titanium files, which are manufactured by machining, stainless steel files are manufactured by torsion. In nickel-titanium files, the electropolishing procedure is intended to smooth or eliminate cracks or defects that may remain as a result of machining 7 . The results of electropolishing of the nickel-titanium alloy has been evaluated by SEM and surface roughness analysis ${ }^{7,28}$.

Although the Ready Steel K-Flexofile ${ }^{\circledR}$ manufacturers say they electropolish these stainless steel files (Bolle A, 2018, communication from the manufacturer, unpublished data), we found that these were the files with the greatest surface roughness. Nevertheless, the same group -Ready Steel K-Flexofile ${ }^{\circledR}-$ had the greatest resistance to fracture due to cyclic fatigue. One possible explanation is the shape and appearance of the roughness on these files, which was found by FVM to have no cracks, angles or edges that might concentrate tensions, thereby contributing to initiation of crack formation. On the contrary, this roughness presents regularly distributed, rounded plastic surface microdeformations, probably as a result of some type of electropolishing, which may induce greater resistance to cyclic fatigue by introducing residual compression stress. It has been shown that the aforementioned procedures for stainless steel alloy, such as electropolishing, are not necessarily associated to less roughness ${ }^{8}$.

With regard to the presence of residual compression stress, Yibo et al. ${ }^{29}$ reported the use of ultrasonic cavitation in stainless steel alloys, which increased surface roughness while at the same time generating residual compression stress that increases microhardness and resistance to cyclic fatigue. Moreover, Kadarno et al. ${ }^{30}$ reported a mechanical micro-punching process on stainless steel sheets that resulted in a regular plastic deformation surface that increased resistance to cyclic fatigue. The same authors mentioned that residual compression forces are responsible for this greater resistance to cyclic fatigue.

Abbott et al. ${ }^{31}$ observed that stainless steel surfaces present regular undulations and variations 
after manufacturing and electropolishing processes, which is consistent with our findings, in which FVM shows regularly distributed undulating surface deformations, which may be attributed to an electropolishing process in stainless steel files.

We suggest that, in contrast to residual tensile stresses, which are detrimental to material resistance and promote crack formation ${ }^{32}$, the presence of residual compressive stresses in the surface of a metal such as endodontic file stainless steel may prevent the propagation of cracks occurring as a result of repeated stress, thereby reducing the likelihood of fracture due to cyclic fatigue.

In contrast to our results, lower roughness has been reported to be associated to resistance to cyclic fatigue. Silva et al. ${ }^{33}$ reported that heat treatments reduce roughness and increase resistance to cyclic fatigue of rotary nickeltitanium files. Likewise, Vaz-García et al. ${ }^{34}$ reported that the smooth surface of nickeltitanium endodontic files is associated to a lower likelihood of cracks initiating due to fatigue and leading to instrument fracture ${ }^{34}$. Lopes et al. ${ }^{7}$ found that instruments treated with surface polishing, which are therefore smoother, are more resistant to cyclic fatigue than instruments not subjected to polishing. The difference from our results may be explained by two factors: (1) the manufacturing process, since stainless steel files are manufactured by torsion, while nickel-titanium files are machined, and (2) the difference may lie in the material itself, i.e., the mechanical properties of stainless steel are different from those of nickel-titanium, which may affect behavior under cyclic fatigue.

One limitation of this study was not being able to determine the type of electropolishing procedure performed by the manufacturer for

\section{FUNDING}

None.

\section{DECLARATION OF CONFLICTING INTERESTS}

The authors declared no potential conflicts of interest with respect to the research, authorship, and/or publication of this article. the Ready Steel K-Flexofile ${ }^{\circledR}$ group, because it is industry confidential information and therefore unavailable to the public. Thus, all the findings described herein were deduced based on observations of the surface of the material and on the cyclic fatigue resistance assay.

The fracture surface characteristics observed were similar to those reported by Haikel et al. ${ }^{23}$, who also observed stainless steel file fractures by SEM. Our study observed presence of ductile fracture and fibrous areas with presence of dimples characteristic of overload and plastic deformation.

Evaluation of resistance to fracture due to cyclic fatigue of different nickel-titanium rotary files has found that the instrument with the longest fractured fragment was the one with highest resistance to fracture due to cyclic fatigue ${ }^{35,36}$. These results agree with ours, since we too found that the file with the longest fragment was the one with greatest resistance to fracture due to cyclic fatigue.

Based on our search in the literature, this is the first article to relate surface roughness to cyclic fatigue resistance in stainless steel files. It also uses focus variation microscopy to evaluate the topography of surface roughness of files, of which the main use is representing roughness by means of $S a$ area parameters.

Further studies are needed to evaluate resistance to dynamic and torsional cyclic fatigue in rotary and manual endodontic files in reciprocating motion or continuous rotation.

To conclude, files in the Ready Steel K-Flexofile ${ }^{\circledR}$ group have significantly higher resistance to fracture due to cyclic fatigue than the other instruments evaluated, as well as significantly higher roughness. As moderate positive correlation was found between length of the fractured fragment and roughness.

\section{CORRESPONDENCE}

Dr. Javier Niño-Barrera

Calle 135 \# 58B -21 Interior 2 Apartamento 302.

Bogotá, Colombia

jlninob@unal.edu.co 


\section{REFERENCES}

1. BoesslerC, Paque F, Peters OA. The effect of electropolishing on torque and force during simulated root canal preparation with ProTaper shaping files. J Endod 2009;35:102-106.

2. Ozyurek T, Yilmaz K, Uslu G, Plotino G. The effect of root canal preparation on the surface roughness of WaveOne and WaveOne Gold files: atomic force microscopy study. Restor Dent Endod 2018;43:e10.

3. Arnold JW, Bailey GW. Surface finishes on stainless steel reduce bacterial attachment and early biofilm formation: scanning electron and atomic force microscopy study. Poult Sci 2000;79:1839-1845.

4. Brzhozovskii B, Brovkova M, Gots I, Zinina H, Martynov V. Study of the low-temperature plasma treatment effect on the structure, physical and chemical surface characteristics of 40X13 steel. Heliyon 2019;5:e02388.

5. An G, Liu RJ, Yin GQ. Fatigue Limit of Custom 465 with Surface Strengthening Treatment. Materials (Basel) 2020;13.

6. McGuigan MB, Louca C, Duncan HF. Endodontic instrument fracture: causes and prevention. $\mathrm{Br}$ Dent $\mathrm{J}$ 2013;214:341-348.

7. Lopes HP, Elias CN, Vieira MV, Vieira VT, de Souza LC, Dos Santos AL. Influence of Surface Roughness on the Fatigue Life of Nickel-Titanium Rotary Endodontic Instruments. J Endod 2016;42:965-968.

8. Sutow EJ. The influence of electropolishing on the corrosion resistance of $316 \mathrm{~L}$ stainless steel. J Biomed Mater Res 1980;14:587-595.

9. Weldon LM, McHugh PE, Carroll W, Costello E, O'Bradaigh C. The influence of passivation and electropolishing on the performance of medical grade stainless steels in static and fatigue loading. J Mater Sci Mater Med 2005;16:107-117.

10. Rodrigues RC, Lopes HP, Elias CN, Amaral G, Vieira VT, De Martin AS. Influence of different manufacturing methods on the cyclic fatigue of rotary nickel-titanium endodontic instruments. J Endod 2011;37:1553-1557.

11. Gündoğar M, Uslu G, Özyürek T, Plotino G. Comparison of the cyclic fatigue resistance of VDW.ROTATE, TruNatomy, 2Shape, and HyFlex CM nickel-titanium rotary files at body temperature. Restor Dent Endod 2020;45.

12. Darcey J, Taylor C, Roudsari RV, Jawad S, Hunter M. Modern Endodontic Principles Part 3: Preparation. Dent Update 2015;42:810-812, 815-818, 821-812.

13. Jin SY, Lee W, Kang MK, Hur B, Kim HC. Single file reciprocating technique using conventional nickel-titanium rotary endodontic files. Scanning 2013;35:349-354.

14. Fernandez-Pazos G, Martin-Biedma B, Varela-Patino P, Ruiz-Pinon M, Castelo-Baz P. Fracture and deformation of ProTaper Next instruments after clinical use. J Clin Exp Dent 2018;10:e1091-e1095.

15. Ehrhardt IC, Zuolo ML, Cunha RS, De Martin AS, Kherlakian D, Carvalho MC, Bueno CE. Assessment of the separation incidence of mtwo files used with preflaring: prospective clinical study. J Endod 2012;38:1078-1081.

16. Plotino G, Grande NM, Cordaro M, Testarelli L, Gambarini G. A review of cyclic fatigue testing of nickel-titanium rotary instruments. J Endod 2009;35:1469-1476.

17. Tanomaru-Filho M, Galletti Espir C, Carolina Vencao A, Macedo-Serrano N, Camilo-Pinto J, Guerreiro-Tanomaru J. Cyclic Fatigue Resistance of Heat-Treated Nickel-Titanium Instruments. Iran Endod J 2018;13:312-317.
18. Lopes HP, Ferreira AA, Elias CN, Moreira EJ, de Oliveira JC, Siqueira JF, Jr. Influence of rotational speed on the cyclic fatigue of rotary nickel-titanium endodontic instruments. J Endod 2009;35:1013-1016.

19. Gambarini G, Galli M, Di Nardo D, Seracchiani M, Donfrancesco O, Testarelli L. Differences in cyclic fatigue lifespan between two different heat treated NiTi endodontic rotary instruments: WaveOne Gold vs EdgeOne Fire. J Clin Exp Dent 2019;11:e609-e613.

20. Martins JNR, Nogueira Leal Silva EJ, Marques D, Ginjeira A, Braz Fernandes FM, De Deus G, Versiani MA. Influence of Kinematics on the Cyclic Fatigue Resistance of Replicalike and Original Brand Rotary Instruments. J Endod 2020;46:1136-1143.

21. Al-Qudah AA, Mitchell CA, Biagioni PA, Hussey DL. Thermographic investigation of contemporary resincontaining dental materials. J Dent 2005;33:593-602.

22. Kwon SJ, Park YJ, Jun SH, Ahn JS, et al. Thermal irritation of teeth during dental treatment procedures. Restor Dent Endod 2013;38:105-112.

23. Haikel Y, Gasser P, Allemann C. Dynamic fracture of hybrid endodontic hand instruments compared with traditional files. J Endod 1991;17:217-220.

24. Gambarini G, Plotino G, Sannino G, Grande NM, et al. Cyclic fatigue of instruments for endodontic glide path. Odontology 2015;103:56-60.

25. Piasecki L, Al-Sudani D, Rubini AG, Sannino G, et al. Mechanical resistance of carbon and stainless steel hand instruments used in a reciprocating handpiece. Ann Stomatol (Roma) 2013;4:259-262.

26. Townsend A, Senin N, Blunt L, Leach RK, Taylor JS. Surface texture metrology for metal additive manufacturing: a review. Precis Eng 2016;46:34-47.

27. Kapłonek W, Nadolny K, Królczyk GM. The Use of FocusVariation Microscopy for the Assessment of Active Surfaces of a New Generation of Coated Abrasive Tools. Meas Sci Rev 2016;16:42-53.

28. Shen Y, Winestock E, Cheung GS, Haapasalo M. Defects in nickel-titanium instruments after clinical use. Part 4: an electropolished instrument. J Endod 2009;35:197-201.

29. Yibo G, Benxin W, Ze L, Yun Zh, Ninggang Sh, Hongtao D. Ultrasonic Cavitation Peening of Stainless Steel and Nickel Alloy. J Manuf Sci e-t ASME 2014;136:014502-014501 014502-014506.

30. Kadarno P, Mori K-I, Abe Y, Abe T. Punching process including thickening of hole edge for improvement of fatigue strength of ultra-high strength steel sheet. Manuf Review 2014;1:4.

31. Abbott AP, Capper G, McKenzie KJ, Glidle A, Ryder KS. Electropolishing of stainless steels in a choline chloride based ionic liquid: an electrochemical study with surface characterisation using SEM and atomic force microscopy. Phys Chem Chem Phys 2006;8:4214-4221.

32. Kim HC, Cheung GS, Lee CJ, Kim BM, Park JK, Kang SI. Comparison of forces generated during root canal shaping and residual stresses of three nickel-titanium rotary files by using a three-dimensional finite-element analysis. J Endod 2008;34:743-747.

33. Silva EJNL, Giraldes JFN, de Lima CO, Vieira VTL, Elias $\mathrm{CN}$, Antunes HS. Influence of heat treatment on torsional 
resistance and surface roughness of nickel-titanium instruments. Int Endod J 2019;52:1645-1651.

34. Vaz-Garcia ES, Vieira VTL, Petitet NPdSF, Moreira EJL, et al. Mechanical Properties of Anatomic Finishing Files: XPEndo Finisher and XP-Clean. Braz Dent J 2018;29:208213.

35. Serefoglu B, Kaval ME, Micoogullari Kurt S, Caliskan MK.
Cyclic Fatigue Resistance of Novel Glide Path Instruments with Different Alloy Properties and Kinematics. J Endod 2018;44:1422-1424.

36. Kaval ME, Capar ID, Ertas H. Evaluation of the cyclic fatigue and torsional resistance of novel nickel-titanium rotary files with various alloy properties. J Endod 2016;42:1840-1843. 